\title{
Evaluation of Nutrient Removal Efficiency with Chitosan: Nutrient Composition and Bacterial Removal in Effluents of Nile Tilapia (Oreochromis niloticus) in the Hatchery
}

\author{
Syafiqah Saufie, Abentin Estim, Sitti Raehanah M Shaleh and Saleem Mustafa* \\ Borneo Marine Research Institute, Universiti Malaysia Sabah, Sabah, Malaysia
}

*Corresponding author: Saleem Mustafa, Borneo Marine Research Institute, Universiti Malaysia Sabah, Jalan UMS, 88400 Kota Kinabalu, Sabah, Malaysia, E-mail: saleem@ums.edu.my

Received: 31 Jul, 2021 | Accepted: 07 Sep, 2021 | Published: 13 Sep, 2021

Citation: Saufie S, Estim A, Shaleh SRM, Mustafa S (2021) Evaluation of Nutrient Removal Efficiency with Chitosan: Nutrient Composition and Bacterial Removal in Effluents of Nile Tilapia (Oreochromis niloticus) in the Hatchery. Int J Water Wastewater Treat 7(2): dx.doi. org/10.16966/2381-5299.179

Copyright: (C) 2021 Saufie S, et al. This is an open-access article distributed under the terms of the Creative Commons Attribution License, which permits unrestricted use, distribution, and reproduction in any medium, provided the original author and source are credited.

\begin{abstract}
Effluents from aquaculture systems contain large volumes of chemical substances and microbial load such as polychlorinated biphenyls and antibiotics that are often used to control infection and pathogenic bacteria originating from feed or water. These substances, if discharged, create pollution in the aquatic environment. Mitigating this problem requires implementing appropriate treatment methods. This study investigated the efficiency of uptake of nutrients in the wastewater and reduction of microbial pollution by chitosan. This product is a linear polysaccharide composed of $\beta$-linked D-glucosamine and N-acetyl-D-glucosamine and can be extracted from the shells of shrimps, lobsters, crabs and other crustaceans that are discarded in bulk quantities by seafood restaurants. The performance of laboratory-produced chitosan (S1) which was prepared from shells of Pacific white leg shrimp (Litopenaeus vannamei) was compared with that of the commercial grade chitosan (S2). While the latter was more effective in nitrogen and phosphorus removal and reduction of total faecal coliform, the two products were comparable in the uptake of minerals from the effluents from a tilapia culture system. The results showed that $\mathrm{S} 1$ and $\mathrm{S} 2$ adsorbed the nutrients from aquaculture effluents, especially ammonia ( $\left.\mathrm{NH}_{4}{ }^{+}\right)$, nitrite $\left(\mathrm{NO}_{2}{ }^{-}\right)$, nitrate $\left(\mathrm{NO}_{3}{ }^{-}\right)$and phosphate $\left(\mathrm{PO}_{4}{ }^{3}\right)$. However, differences were evident in terms of the efficiency of their removal and duration of treatment required for the purpose. In this respect, S2 performed better. Moreover, the anti-bacterial activity of S2 was higher than that of S1, and this appeared to be linked to differences in surface features of the two products. The chitosan extracted from shrimp waste and processed locally provides a low-cost solution to the environmental problems caused by aquaculture effluents.
\end{abstract}

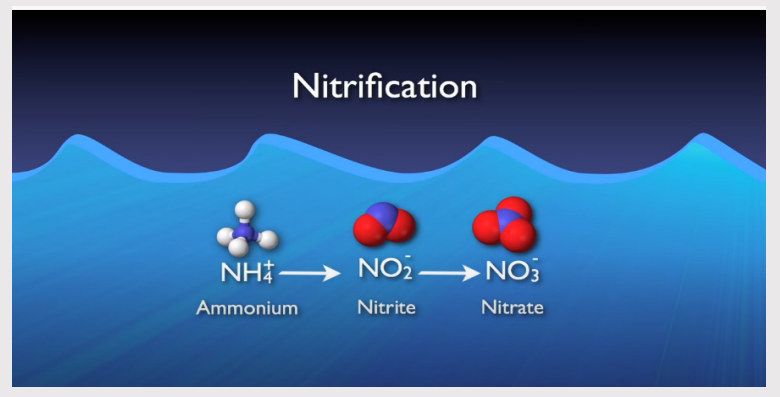

$\mathrm{NH}_{4}^{+}, \mathrm{NO}_{2}, \mathrm{NO}_{3}{ }^{-}, \mathrm{PO}_{4}{ }^{3-}$

Keywords: Wastewater; Eutrophication control; Cost-effective solution; Adsorption efficiency; Environmental footprint

\section{Introduction}

Aquaculture effluents cause pollution of the receiving environment [1]. Their effects depend on several factors, including the volume and chemical composition of the discharge, and the assimilation capacity of the recipient water body [2-4]. Chemical composition of the effluent depends on several factors, including feed quality [5], ration size [6], protein content of feed [7], stocking density [8] and water exchange rate [9]. Among these factors quality of feed given to the fish is considered to a major one since it significantly influences the nature of metabolic substances generated and the products of decomposition of the uneaten feed [10]. Optimum water quality parameters for tilapia growth are dissolved oxygen (more than 3-5 $\mathrm{mg} / \mathrm{L}), \mathrm{pH}(7-8)$, temperature $\left(26-30^{\circ} \mathrm{C}\right)$, total ammonia nitrogen, 
TAN (0.17-3.87 mg/L), nitrite (0.02-0.12 mg/L), nitrate (2-219 $\mathrm{mg} / \mathrm{L})$. Regarding Biochemical Oxygen Demand, BOD, and Chemical Oxygen Demand, COD, the suitable values are less than $10 \mathrm{mg} / \mathrm{L}$ and less than $50 \mathrm{mg} / \mathrm{L}$, respectively (ICAR, 2007). Many techniques have been adopted to treat aquaculture wastewater such as the use of chitosan and microalgae that have coagulating and flocculating ability [11], application of Recirculating Aquaculture System (RAS) which is able to ensure uptake and transformation of nutrient waste into biomass production [12,13], aquaponic system where plants act as biofilter and helps to remediate water quality $[14,15]$, more complex system such as Integrated Multi-Trophic Aquaculture (IMTA) where multiple species of aquatic organisms from different trophic levels are integrated to utilize the waste to create a balanced system to ensure bioremediation of water quality $[14,16]$, Biofloc Technology (BFT) that is distinguished by its ability to promote the growth of a microbial community primarily responsible for water quality maintenance $[17,18]$, combination of aquatic organism and plants in a closed system membrane separation, electrochemical transformation and biodegradation [19]. Recently, interest is rapidly catching up in introducing the concept of circular economy inspired by nature and termed as aquamimicry that simulates natural conditions of aquatic system for integrated production. However, adsorption methods have gained popularity due to relatively low-cost, efficiency, practical convenience and environmental compatibility [7].

The role of chitosan in the adsorption of water pollutants has been receiving more interest in recent years [20-22]. This is considered a low-cost and eco-friendly solution. This study was carried out to investigate the effectiveness of chitosan, a linear polysaccharide composed of $\beta$-linked D-glucosamine and $\mathrm{N}$-acetyl-D-glucosamine, which can be extracted from the shells of shrimps, lobsters, crabs and other crustaceans. The discarded shells of these animals are abundantly available as a waste product and can provide a rich source of the raw material free of cost for chitosan extraction.

Therefore, this investigation has the objective to evaluate the nutrient removal efficiency by chitosan based on effluents from the culture of Nile tilapia (Oreochromis niloticus). This fish is one of the most widely cultured species in the tropical and sub-tropical regions and ranks among the top three in the world in the aquaculture sector [23-25]. The ever-increasing tilapia culture has raised concerns about the management of effluents [23] resulting from the uneaten feed, therapeutic chemicals, solid wastes, dissolved organic matter, such as nitrogen, phosphorus and Total Suspended Solid (TSS) [26-29]. A poor water quality environment for tilapia culture is due to the high amount of toxic waste such as total ammonia nitrogen, nitrite, nitrate and organic matter that decompose, a in water and provide a plague spot environment for bacterial growth, and this condition has been linked to high levels of fish meal or fish oil in aquaculture feed [27,30]. Because tilapia is an affordable fish, only cost-effective methods for managing wastewater from its culture systems will provide a practical solution such as the one developed in this study using chitosan from shrimp shell waste.

\section{Materials and Methods}

\section{Study site}

The study was done at the Fish Hatchery and Chemical Oceanography Laboratory of Borneo Marine Research Institute, Universiti Malaysia Sabah, Kota Kinabalu, Sabah in October 2019.

\section{Water samples collection}

Tilapia wastewater samples were collected from the outlet of juvenile tilapia culture tanks in the Fish Hatchery. Thirty liters of water samples were filtered using $50 \mu \mathrm{m}$ of white nylon net to remove solid waste for carrying out the adsorption test.

\section{Extraction of chitosan}

Sample collection: Shells of the Pacific white leg shrimp (Litopenaeus vannamei) were procured from the SAFMA Kota Kinabalu seafood market on September 2019, and subjected to the process for extraction of chitosan (S1). Its performance was compared with the commercial grade chitosan (trade name Kitosan) (S2) treated with sodium hydroxide obtained from Dasatim Sendirian Berhad, Malaysia. According to the company specifications, this product marketed under the name Kitosan plus TM and is extracted from crustacean shells, and is safe to use for producing organic food. These S1 and S2 products are shown in figure 1.

Demineralization: The shrimp shells were mineralized with $2.5 \%$ $(\mathrm{w} / \mathrm{v})$ of hydrochloric acid $(1: 20 \mathrm{w} / \mathrm{v})$ at room temperature $\left(27^{\circ} \mathrm{C}\right)$ for 6 hours to remove the mineral content from the ground shells. Samples were then filtered to remove the residues and then washed with tap water for at least 30 minutes until the neutral $\mathrm{pH}$ was achieved. Subsequently, the shell residue was dried in the oven for 24 hours at $60^{\circ} \mathrm{C}[16]$.

Deproteinization: The dried mass was treated with $2.0 \%$ of potassium hydroxide solution in a ratio 1:20 (w/v) with constant stirring carried out for 2 hours at $90^{\circ} \mathrm{C}$ to remove protein in the shells. The deproteinized shells were transferred to the oven for 24 hours at $60^{\circ} \mathrm{C}$ until the product was dried [16].

Decolouration and dewatering: The dried shrimp shells were immersed in acetone for 10 minutes and maintained at room temperature to evaporate the solvent followed by washing with the running tap water. The product was then filtered and dried at $60^{\circ} \mathrm{C}$ in the oven for 24 hours [16].

Deacetylation of chitin: Chitin so obtained by the above processing was treated with $40 \%$ sodium hydroxide in the ratio of $1: 15$ and maintained at $105^{\circ} \mathrm{C}$ for 2 hours. Thereafter, the contents were filtered and washed with deionized water until the neutral $\mathrm{pH} 7$ was attained. The resulting chitosan was dried at $60^{\circ} \mathrm{C}$ for 24 hours in the oven at $60^{\circ} \mathrm{C}[31]$. The stepwise process followed for production of chitosan is shown in flow chart (Figure 2).

\section{Adsorption test}

Samples of wastewater from tilapia culture tanks in the fish hatchery were collected and filtered using a normal filter paper. Each filtered sample was transferred to a $3 \mathrm{~L}$ capacity beaker and $1.0 \mathrm{~g} / \mathrm{L}$ of chitosan was added to the beaker while magnetic stirring continued. Aliquots measuring $10 \mathrm{~mL}$ were collected in triplicate at intervals from 1 to 320 minutes $(1,5,10,20,40,80,160$ and 320 minutes). The aliquots were then centrifuged for $3000 \mathrm{rpm}$ and the supernatant was pipette out for transfer into clean test tubes for further water quality analysis [20].

Removal of ammonia $\left(\mathrm{NH}_{4}^{+}\right)$, nitrite $\left(\mathrm{NO}_{2}^{-}\right)$, nitrate $\left(\mathrm{NO}_{3}^{-}\right)$and phosphate $\left(\mathrm{PO}_{4}^{3-}\right)$ : Concentrations $\mathrm{NH}_{4}^{+}, \mathrm{NO}_{2}^{-}, \mathrm{NO}_{3}^{-}, \mathrm{PO}_{4}^{3-}$ were determined using the Hach Ammonia Low-Range Standard Method 10023, Hach Nitrite Low-Range Standard Method 8192, Hach Nitrate High-Range Standard Method 8093 and Hach Phosphate Standard Method 8048, respectively. The optical density was measured using UNICO 2100 spectrophotometer. 


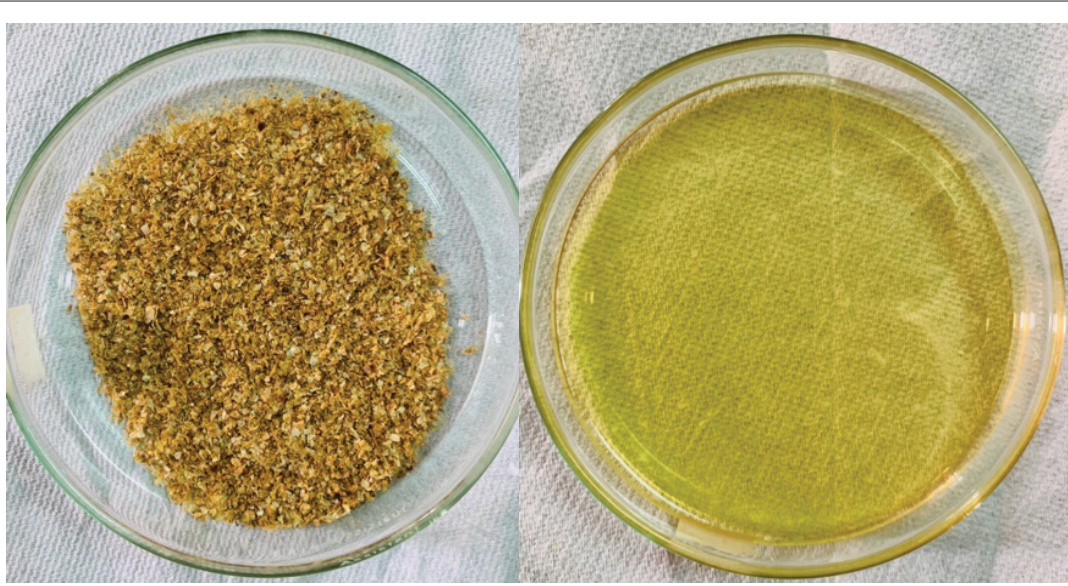

Figure 1: Chitosan products S1 (left) and S2 (right).

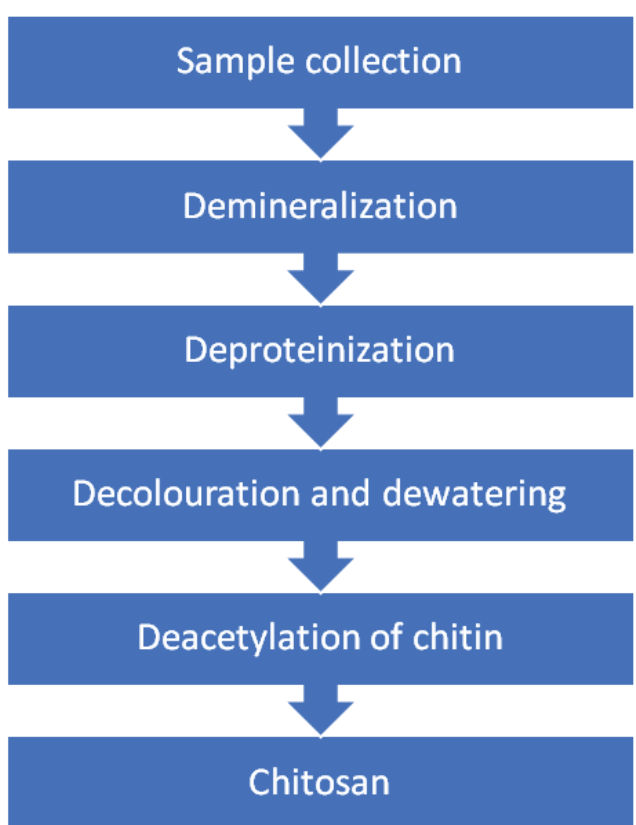

Figure 2: A flow chart showing the methodology followed for of laboratory-produced chitosan..

Percentage removal of effluents was determined by the following equation:

Efficiency of removal $(\%)=\frac{(\mathrm{Ic}-\mathrm{Fc})}{I c} \times 100$

Where,

Ic=Initial Concentration $(\mathrm{mg} / \mathrm{L})$

$\mathrm{Fc}=$ Final Concentration $(\mathrm{mg} / \mathrm{L})$

Pollutant adsorption capacity was measured by the formula:

$Q=\frac{(\mathrm{Ic}-\mathrm{Fc})}{M} \times V$

Where,

$\mathrm{Q}=$ Adsorption Capacity $(\mathrm{mg} / \mathrm{L})$
$\mathrm{Ic}=$ Initial Concentration $(\mathrm{mg} / \mathrm{L})$

$\mathrm{Fc}=$ Final Concentration $(\mathrm{mg} / \mathrm{L})$

$\mathrm{V}=$ Volume of Solution $(\mathrm{L})$

$\mathrm{M}=$ Adsorbent Mass (g)

\section{Determination of nutrient composition in the adsorbent}

Minerals that also serve as nutrients were analysed in the adsorbents. The sample preparation was done according to the wet digestion method. Dry samples were weighed 0.5 gr each and placed in a flask followed by the addition of $10 \mathrm{ml}$ of concentrated $\mathrm{HNO}_{3}$. The samples were maintained at room temperature overnight and then heated at $125^{\circ} \mathrm{C}$ for 4 hours. This was followed by dilution with $12.5 \mathrm{ml}$ of concentrated $\mathrm{HNO}_{3}$ and mixing for a few minutes until amorphous substance appeared to settle at the bottom of the flask. The contents were diluted with $50 \mathrm{~mL}$ of distilled water and filtered on a $0.45 \mu \mathrm{m}$ white filter paper to get a clear solution and were prepared triplicate. This sample was used for quantitative analysis of elemental composition with the help of the Inductively Coupled Plasma Optical Emission (ICP-OES) method.

\section{Bacteria colony count $(\mathrm{CFU} / \mathrm{ml})$}

Another $1 \mathrm{~L}$ wastewater sample collected from Fish Hatchery was immediately put in a freezer without being filtered. The preparation of nutrient media-agar involved mixing of $0.5 \mathrm{gr}$ Rosolic acid with $5 \mathrm{ml}$ of $0.2 \mathrm{NaOH}$ (mixture 1). Subsequently, $26 \mathrm{gm}$ of m-FC agar base was added with $500 \mathrm{ml}$ of distilled water (mixture 2). Next, mixtures 1 and 2 were pooled in a beaker, heated on a hotplate, and brought to simmer. Then, the agar was poured into a plate and allowed to set.

The plate count method was applied for determining the bacterial density. A series of dilutions 10-4, 10-5 and 10-6 of the water sample was done in triplicate. A measured $1.0 \mathrm{ml}$ of diluted water sample was put into $100 \mathrm{ml}$ of distilled water in a conical flask and shaken thoroughly. Thereafter, $100 \mathrm{ml}$ of the mixed sample was filtered with a grid $0.45 \mu \mathrm{m}$ membrane filter. The filtered contents were put on top of the nutrient agar, closed with the lid and sealed with paraffin. Finally, the sealed media was placed into an oven at $45^{\circ} \mathrm{C}$ for 24 hours after which the counting of bacterial colonies were observed and counted in serial dilutions of 10-4, 10-5 and 10-6.

Citation: Saufie S, Estim A, Shaleh SRM, Mustafa S (2021) Evaluation of Nutrient Removal Efficiency with Chitosan: Nutrient Composition and Bacterial Removal in Effluents of Nile Tilapia (Oreochromis niloticus) in the Hatchery. Int J Water Wastewater Treat 7(2): dx.doi.org/10.16966/2381-5299.179 


\section{Statistical analysis}

The statistical analysis of the adsorption efficiency (\%) of $\mathrm{NH}_{4}^{+}, \mathrm{NO}_{2}$ , $\mathrm{NO}_{3}, \mathrm{PO}_{4}^{3-}$ and nutrient composition of $\mathrm{S} 1$ and $\mathrm{S} 2$ were performed by Independent Sample T-test, while faecal coliform bacteria count was subjected to Paired Samples t-test in Statistical Package of the Social Sciences (SPSS) software (version of 22.0). The data variability was done in triplicate and expressed as mean standard error with significant difference of $\mathrm{P}<0.05$, was between treatments characterised by small letter (if any).

\section{Results}

\section{Nutrient removal by adsorption}

The initial concentrations of $\mathrm{NH}_{4}^{+}, \mathrm{NO}_{2}, \mathrm{NO}_{3}{ }^{-}, \mathrm{PO}_{4}^{3-}$ in the tilapia wastewater were $3.3 \mathrm{mg} / \mathrm{L}, 3 \mathrm{mg} / \mathrm{L}, 3 \mathrm{mg} / \mathrm{L}$ and $4.9 \mathrm{mg} / \mathrm{L}$, respectively. The data shows (Figure 3) the efficiency of $\mathrm{NH}_{4}{ }^{+}$removal with the S2 treatment increased after 20 minutes whence it was 55.4\%. It was more efficient than S1 treatment that achieved $47.9 \%$ removal. After 80 minutes, the adsorption was constant, reaching the equilibrium or saturated state. The removal of $\mathrm{NO}_{2}$ by $\mathrm{S} 2$ treatment amounted to $53 \%$ after 40 minutes and $52 \%$ with S1 treatment. After 40 minutes, the adsorption of $\mathrm{NO}_{2}$ became constant with both $\mathrm{S} 1$ and $\mathrm{S} 2$ treatments until the end of the experiment. It was different in the case of $\mathrm{NO}_{3}$ where the highest removal was observed after 1 minute, amounting to $56.7 \%$ in S2, but $48.3 \%$ in S1 and that too after 20 minutes of treatment. Interestingly, after 80 minutes the graph for S2 showed a declining trend by the release of adsorbate back to the solvent, marking a desorption condition after a saturated stage of adsorption. The pattern of removal of $\mathrm{PO}_{4}^{3-}$ was different, with $32 \%$ in S2 and only $10.2 \%$ in $\mathrm{S} 1$ treatment after 1 minute of agitation. The maximum removal was observed after 80 minutes when it reached $72.0 \%$ for S2 and about 50\% removal can be seen in S2 at $80 \mathrm{~min}$. Statistically, there is no significant difference $(\mathrm{p}>0.05)$ detected between $\mathrm{S} 1$ and $\mathrm{S} 2$ treatments in the removal efficiency (\%) of $\mathrm{NH}_{4}^{+}, \mathrm{NO}_{2}, \mathrm{NO}_{3}^{-}$, but was significant for $\mathrm{PO}_{4}^{3-}(\mathrm{P}<0.05)$.

\section{Adsorption capacity test}

The dosage of $1.0 \mathrm{~g} / \mathrm{L}$ of chitosan used in this study did not result in linear equilibrium in adsorption of some nutrients, most likely due to competition with other substance and chemicals such as dyes, metals, ions, drugs or hormones, antibiotics that may present in the solution for the active sites known as interference in adsorption and desorption behavior. It may also because the dosage of chitosan added into the treatment was not be sufficient to bind with the wastewater molecules. The maximum adsorption of $\mathrm{NH}_{4}^{+}, \mathrm{NO}_{2}$, $\mathrm{NO}_{3}{ }_{3}, \mathrm{PO}_{4}{ }^{3-}$ by $\mathrm{S} 1$ and $\mathrm{S} 2$ is shown in table 1 . However, there was no significant difference as far as the adsorption capacity of S1 and S2 is concerned.

\section{Determination of nutrient composition of chitosan}

The nutrient composition of S1 and S2 are shown in figure 3, figure $4 \mathrm{~A}$ and $4 \mathrm{~B}$. The results revealed that there were no heavy metal elements in the treatments. This could be because the source of $S 1$ and S2 was the same (shrimp shells). They have almost the same nutrient composition where $\mathrm{Na}$ and $\mathrm{Ca}$ occurred in significant amounts. Minor differences $(\mathrm{P}>0.05)$ were noticed in the concentrations of $\mathrm{K}, \mathrm{Ba}, \mathrm{Al}$, $\mathrm{Zn}, \mathrm{Fe}, \mathrm{Mg}$ as well as $\mathrm{Rb}, \mathrm{Sr}, \mathrm{Se}, \mathrm{Sr}$ and $\mathrm{Mn}$.

\section{Bacterial colony count $(\mathrm{CFU} / \mathrm{ml})$}

The faecal coliform count was used to monitor the water quality conditions and the risk of waterborne disease in aquatic ecosystems [28]. The initial bacteria colony count of faecal coliform was 1.62 $\times 106$ (Figure 5A). After treatment with S1, it decreased to 1.08 $\times 106$ (Figure $5 \mathrm{~B}$ ), and a sharp decline to $0.23 \times 106$ was observed

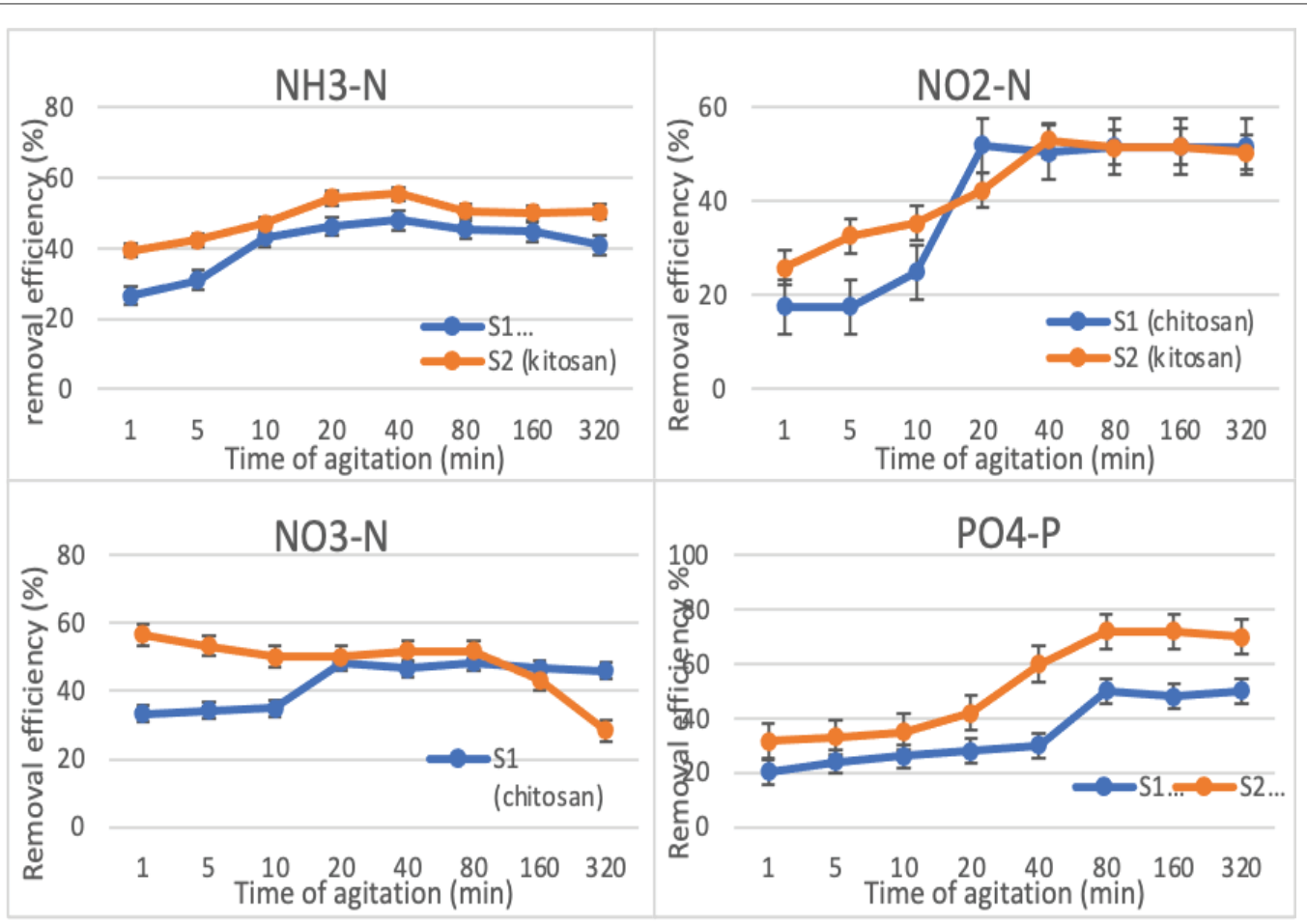

Figure 3: Effect of duration of treatment by agitation ( $\mathrm{min}$ ) on the removal efficiency (\%) of $\mathrm{NH}_{4}{ }^{+}, \mathrm{NO}_{2}{ }^{-}, \mathrm{NO}_{3}$ and $\mathrm{PO}_{4}{ }^{3-}$ for $\mathrm{S} 1$ and $\mathrm{S} 2$.

Citation: Saufie S, Estim A, Shaleh SRM, Mustafa S (2021) Evaluation of Nutrient Removal Efficiency with Chitosan: Nutrient Composition and Bacterial Removal in Effluents of Nile Tilapia (Oreochromis niloticus) in the Hatchery. Int J Water Wastewater Treat 7(2): dx.doi.org/10.16966/2381-5299.179 
Table 1: Adsorption efficiency of $\mathrm{S} 1$ and $\mathrm{S} 2$ for $\mathrm{NH}_{4}{ }^{+}, \mathrm{NO}_{2}, \mathrm{NO}_{3}{ }_{3}^{-}$and $\mathrm{PO}_{4}{ }_{4}^{3-}$.

\begin{tabular}{|c|c|c|c|c|}
\hline Treatment & $\begin{array}{c}\text { Ammonia, } \mathbf{Q} \\
\text { (mg/g) }\end{array}$ & $\begin{array}{c}\text { Nitrite, } \mathbf{Q} \\
\text { (mg/g) }\end{array}$ & $\begin{array}{c}\text { Nitrate, Q } \\
\text { (mg/g) }\end{array}$ & $\begin{array}{c}\text { Phosphate, Q } \\
\text { (mg/g) }\end{array}$ \\
\hline S1 & $10.8 \pm 0.1$ & $7.80 \pm 0.3$ & $1.25 \pm 0.15$ & $12.25 \pm 0.2$ \\
\hline S2 & $11.1 \pm 0.1$ & $7.95 \pm 0.3$ & $8.5 \pm 0.1$ & $17.15 \pm 0.2$ \\
\hline
\end{tabular}

Table 2: Average efficiency of S1 and S2 in removing faecal bacteria in the tilapia wastewater.

\begin{tabular}{|c|c|}
\hline Treatment & Average efficiency (\%) \\
\hline S1 & 32.82 \\
\hline S2 & 85.45 \\
\hline
\end{tabular}

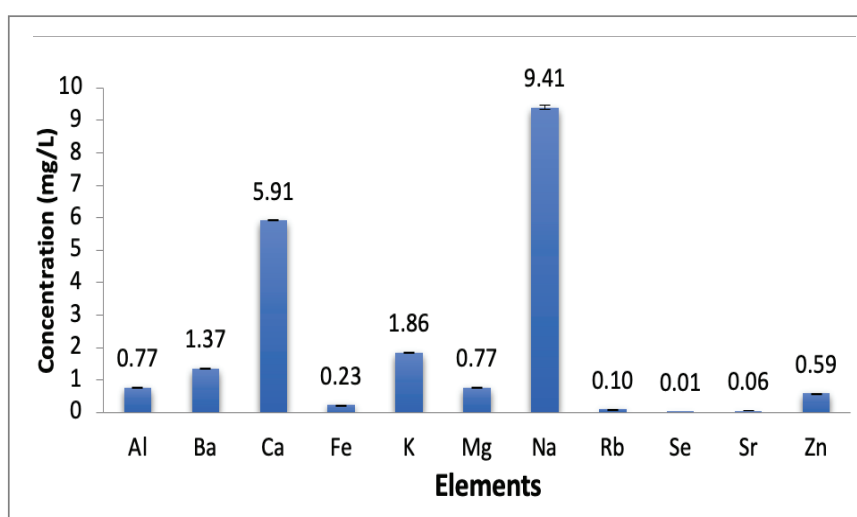

Figure 4A: Nutrient composition of S1.

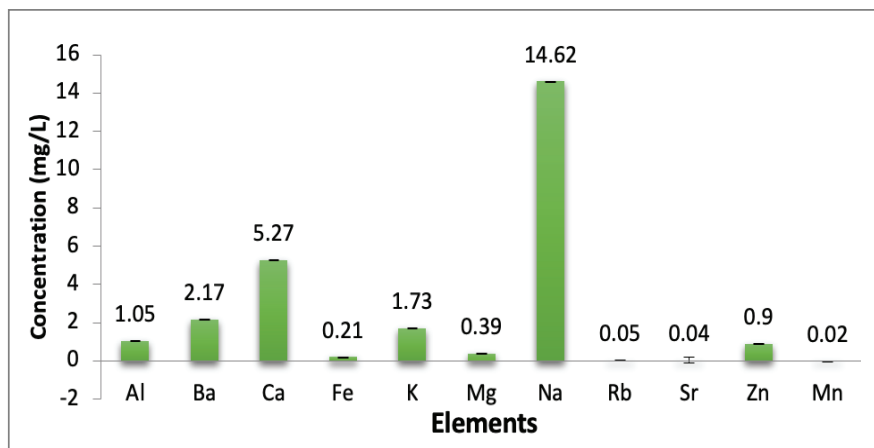

Figure 4B: Nutrient composition of S2.

following the treatment with S2 (Figure 5C). It is evident from table 2 that S2 removed a higher percentage of faecal coliform than S1. The antibacterial activity of chitosan can be affected by factors such as temperature, dosage (concentration), purity and target bacteria [32]. A paired t-test reveals a statistical difference $(\mathrm{P}<0.05)$ between $\mathrm{S} 1$ and S2 treatments in the faecal coliform count.

\section{Discussion}

The presence of reactive hydroxyl functional group (-OH) and amine (-NH2) in the chitosan chemical structure makes it effective as an adsorbent material for the removal of contaminants from wastewater [7]. A high percentage of nitrogen on the porous surface of chitosan suggests the existence of an amino-functional group that facilitates adsorption interactions between chitosan and wastewater molecules [31]. The modified or treated chitosan that develops by grafting amino, quaternary ammonium, carboxyl and thiol groups possesses a higher density of reactive groups [33]. This enhances the ability of the product to carry out more functions with higher selectivity and affinity in a wide range of applications.

Since most of the compounds causing pollution are negatively charged, the unique features of chitosan as biopolymers are more effective than other mineral coagulants such as aluminium sulphate in removing undesirable chemicals from the aqueous solution. By virtue of being a single cationic biopolymer the chitosan neutralizes and removes the anionic suspended colloidal particles by coagulationflocculation [34].

The adsorption of $\mathrm{NH}_{4}^{+}$into chitosan is mainly due to the ionic interaction between this positively charged molecule and negative adsorption sites of the adsorbent (-COO-). This is further proved by performing an adsorption study involving a mixed solution containing positively charged $\mathrm{NH}_{4}^{+}$and negatively charged $\mathrm{PO}_{4}^{3-}$ . At the end of the trial, the concentration of $\mathrm{PO}_{4}^{3-}$ was equivalent to the initial concentration of $\mathrm{NH}_{4}^{+}$, indicating that the adsorbed electrostatic attraction is most likely responsible for the adsorption of $\mathrm{NH}_{4}^{+}$[35]. Similarly, for the other nutrients, namely, $\mathrm{NO}_{2}^{-}, \mathrm{NO}_{3}^{-}$ , $\mathrm{PO}_{4}{ }^{3-}$ the adsorption mechanism was mainly due to electrostatic attraction between quaternary sites' positively charged cations and the negatively charged anion [7]. A rapid and high level of absorption of nitrate into chitosan (Figure 2) can be attributed to the presence of nitrogen functional group $\mathrm{N}^{+}\left(\mathrm{C}_{2} \mathrm{H}_{5}\right)_{3}$. The evidence pointing to the ion exchange as being responsible for this adsorption mechanism has been presented by Appunni S, et al. [36].

Nitrate is the final product of the nitrification process in the wastewater and phosphate is a part of the chemicals in the waste originating from fish culture, including the uneaten feed and excrement. Generally, these two compounds have a noticeable presence in tilapia wastewater. Figure 2 shows that the percentage removal of phosphate is $15.3 \%$ higher than that of nitrate. This is mainly because phosphate adsorption capacities are greater than nitrate due to the ionic potential [37]. These findings serve to show that the polymers like chitosan tend to have a greater affinity towards ions with higher atomic number and valence.

This accounts for the three anions: $\mathrm{PO}_{4}^{3-}>\mathrm{OH}^{-}>\mathrm{NO}_{3}^{-}$having higher adsorption of phosphate compared to nitrate [7]. Even though, most of the fish can tolerate very high concentration of nitrate up to $90 \mathrm{mg} / \mathrm{L}$ without any bad side effect and concentration of more than $300 \mathrm{mg} / \mathrm{L}$ can cause nitrate toxicity and cause disturbance on osmoregulation of the fish [26].

Generally, the percentage of removal of $\mathrm{NH}_{4}^{+}, \mathrm{NO}_{2}^{-}, \mathrm{NO}_{3}^{-}, \mathrm{PO}_{4}^{3-}$ was better in $\mathrm{S} 2$ than $\mathrm{S} 1$ because of the differences in physical features of their surface. The product S1 was in the form of flakes, whereas S2 was in a powder state. Differences in these physical features are known to influence the adsorption [25]. The chitosan flakes have a rough surface and are lumpy, whereas chitosan powder has numerous interparticle pores that are highly diffused. Wu FC, et al. [38] also discussed this matter and highlighted that chitosan flakes have more rigid pore structures that are a steric hindrance to amino groups compared to powder that has a loose pore structure that facilitates the adsorption. The adsorption capacity was higher with smaller particle size [39] because the chemical reaction mostly occurs on the surface layer of chitosan so obviously smaller and more numerous particles will be more effective in adsorption [40]. Results presented in table 1 are consistent with these reports. The highest adsorbed wastewater nutrient was $\mathrm{PO}_{4}^{3-}(12.25 \pm 0.2 \mathrm{mg} / \mathrm{g})$ followed by $\mathrm{NH}_{4}^{+}, \mathrm{NO}_{2}^{-}$and 

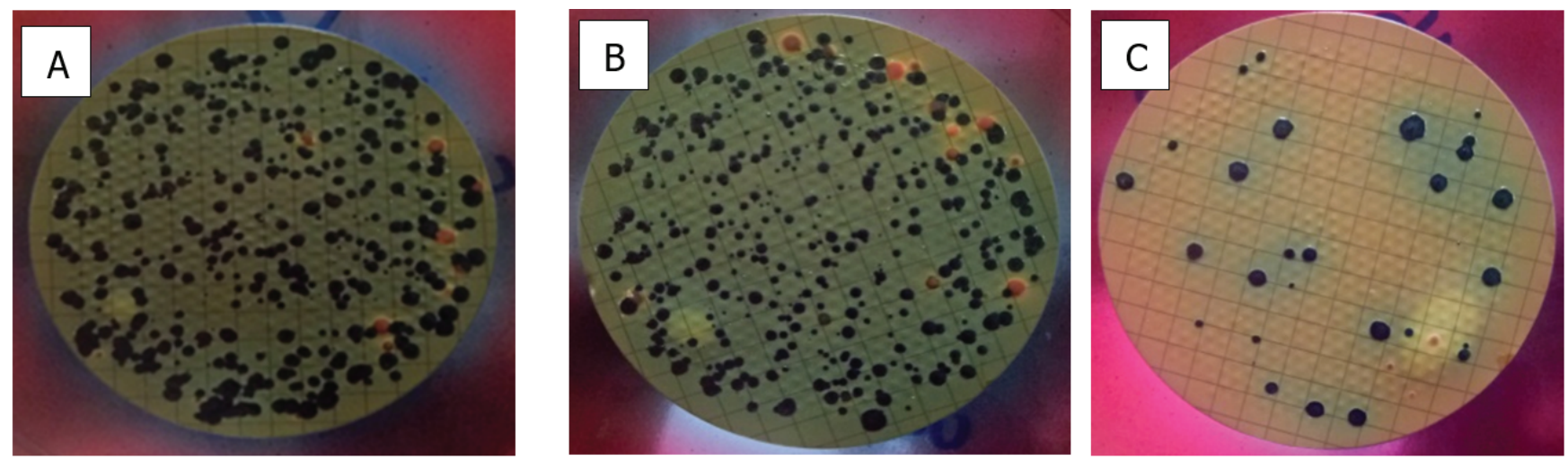

Figure 5: Faecal bacterial colonies (CFU/ml) in the tilapia wastewater effluents (A) after S1 (B) and S2 (C) treatments.

$\mathrm{NO}_{3}$. Concordant results were obtained earlier by Zadinelo IV, et al. [31] and Bernardi F, et al. [20] who suggested that chitosan structure selectivity tends to $\mathrm{PO}_{4}^{3-}$ compared to the other wastewater compound $\left(\mathrm{NH}_{4}^{+}, \mathrm{NO}_{2}^{-}\right.$and $\left.\mathrm{NO}_{3}^{-}\right)$, in disagreement with the views of $\mathrm{Wu} \mathrm{FC}$, et al. [35].

Concentrations of the trace elements (Be, B, Na, Mg, P, K, Ca, $\mathrm{Ti}, \mathrm{V}, \mathrm{Cr}, \mathrm{Mn}, \mathrm{Fe}, \mathrm{Co}, \mathrm{Ni}, \mathrm{Cu}, \mathrm{Zn}, \mathrm{As}, \mathrm{Cd}, \mathrm{Sn}, \mathrm{Sb}, \mathrm{Hg}$ and $\mathrm{Pb}$ ) in the chitosan were low and of normal occurrence [41], posing no risk [42]. Relatively high levels of Ca in S1 and S2 (Figures 3 and 4) is due to calcium carbonate being one of its major components [22]. The source of the high level of $\mathrm{Na}$ is obviously because of its uptake from the seawater [43-48].

Regarding the effect of chitosan on the coliform bacteria, it is evident from the data presented in figure 5 that $S 1$ treatment did not make any appreciable difference from the untreated effluent. However, S2 treatment markedly reduced the bacterial density. This antibacterial activity appears to be linked to the surface area and particle size of chitosan. Ardila N, et al., [49] have suggested that a decrease in chitosan particle size increases the antibacterial activity. S2 provided a larger specific surface area compared to S1. Chung YC, et al. [50] have provided details of the mechanism of antibacterial activity of chitosan. These authors have suggested a two-step process: separation between the bacteria cell wall and cell membrane and followed by the destruction of the cell wall by chitosan. The presence of inorganic substances, including $\mathrm{Ca}, \mathrm{Mg}, \mathrm{Ba}, \mathrm{Na}$ influences this process but it depends on their relative proportions [32]. These reports support role of chitosan as a natural bactericide and emphasize its use in aquaculture effluent treatment [51-54].

\section{Conclusion}

It can be concluded that chitosan possesses the attributes required for adsorption of nutrients that cause pollution if released into the environment. These nutrients include $\mathrm{NH}_{4}^{+}, \mathrm{NO}_{2}{ }^{-}, \mathrm{NO}_{3}{ }^{-}$and $\mathrm{PO}_{4}^{3-}$ in addition to faecal coliform bacteria that are encountered in the waste water from Nile tilapia culture systems. The fact that the product was extracted from discarded shrimp shells makes it economical to use. This approach is also consistent with the concept of circular economy that is currently being promoted to transform aquaculture into a more environment-friendly and low-carbon food production system. Further investigations can be carried out for enhancing the adsorbing efficiency of the local preparation by combining it with low-cost carbonaceous materials or biochar from weeds or discarded biomass with high surface area and porosity.

\section{Acknowledgements}

We would like to thank the encouragement provided by the ongoing the MYSUN program of ERASMUS+.

\section{References}

1. Justino CIL, Duarte KR, Freitas AC, Panteleitchouk TSL, Duarte AC, et al. (2016) Contaminants in aquaculture: Overview of analytical techniques for their determination. TrAC Trends analytical Chem 80: 293-310.

2. Borges FF, Amaral LA, De Stefani MV (2012) Characterization of effluents from bullfrog (Lithobates catesbeianus, Shaw, 1802) in grow-out ponds. Acta Limnologica Brasilliensia 24: 160-166.

3. Mercante CTJ, Vaz-Dos-Santos AM, de Almeida Bispo Moraes M, Pereira JS, Lombardi JV (2014) Bullfrog (Lithobates catesbeianus) farming system: water quality and environmental changes. Acta Limnol Bras Brasilliensia 26: 9-17.

4. Osti JAS, do Carmo CF, Cerqueira MAS, Giamas MTD, Peixoto AC, et al. (2020) Nitrogen and phosphorus removal from fish farming effluents using artificial floating islands colonized by Eichhornia crassipes. Aquaculture Reports.

5. Kong W, Huang S, Yang Z, Shi F, Feng Y, et al. (2020) Fish feed quality is a key factor in impacting aquaculture water environment: evidence from incubator experiments. Sci Rep 10: 187.

6. Dauda AB, Ajadi A, Tola-Fabunmi AS (2019) Waste production in aquaculture: sources, components and managements in different culture systems. Aquaculture Fisheries 4: 81-88.

7. Wang J, Zhuang S (2018) Removal of various pollutants from water and wastewater by modified chitosan adsorbents. Crit Rev Environ Sci Technol 47: 2331-2386.

8. Al Tawaha AR, Wahab PEM, Jaafar HB, Kee-Zuan AT, Hassan MZ (2021) Effects of Fish Stocking Density on Water Quality, Growth Performance of Tilapia (Oreochromis niloticus) and Yield of Butterhead Lettuce (Lactuca sativa) Grown in Decoupled Recirculation Aquaponic Systems. J Ecol Eng 22: 8-19.

9. Wang L, Xu Z, Fu Y, Chen Y, Pan, Z, et al. (2018) Comparative analysis on adsorption properties and mechanisms of nitrate and phosphate by modified corn stalks. RSC Adv 8: 36468-36.476.

Citation: Saufie S, Estim A, Shaleh SRM, Mustafa S (2021) Evaluation of Nutrient Removal Efficiency with Chitosan: Nutrient Composition and Bacterial Removal in Effluents of Nile Tilapia (Oreochromis niloticus) in the Hatchery. Int J Water Wastewater Treat 7(2): dx.doi.org/10.16966/2381-5299.179 
10. Amirkolaie KA (2011) Reduction in the environmental impact of waste discharged by fish farms through feed and feeding. Rev Aquaculture 3: 19-26.

11. Lugo LA, Thorarinsdottir RI, Bjornsson $\mathrm{S}$, Palsson OP, Skulason $\mathrm{H}$, et al. (2020) Remediation of aquaculture wastewater using the microalga Chlorella sorokiniana. Water 12: 3144.

12. Badiola M, Basurko OC, Piedrahita R, Hundley P, Mendiola D (2018) Energy use in recirculating aquaculture systems (RAS): A review. Aquacultural Engineering 81: 57-70.

13. Enriquez M, Alexander Y, Maia, Domingos AA, Romero G, et al. (2019) Comparison of sludges produced from two different recirculating aquaculture systems (RAS) for recycle and disposal. Aquaculture 502: 87-96.

14. Mustafa S, Estim A, Saufi A (2019) Biodynamics in tropical integrated aquaculture systems and challenges in producing organic food using low-carbon methods. BJoMSA 3: 1-8.

15. Saufie S, Estim A, Shalleh SRM, Mustafa S (2020) Production efficiency of green beans integrated with tilapia in a circular farming system of media-filled aquaponics. Spanish Journal of Agricultural Research 18: e0611.

16. Sumbing MV, Al-Azad S, Estim A, Mustafa S (2016) Growth performance of spiny lobster Panulirus ornatus in land-based Integrated Multi-Trophic Aquaculture (IMTA) system. Transactions on Science and Technology, 3: 143-149.

17. Abakari G, Luo G, Meng H, Yang Z, Owusu-Afriyie G, et al. (2020) The use of biochar in the production of tilapia (Oreochromis niloticus) in a biofloc technology system-BFT. Aquacultural Engineering 91: 102123.

18. Brandao H, Xavier IV, Santana GKK, Santana HJK, Krummenauer D, et al. (2021) Heterotrophic versus mixed BFT system: impacts on water use, suspended solids production and growth performance of Litopenaeus vannamei. Aquacultural Engineering 95: 102194.

19. Sarode S, Upadhyay P, Khosa MA, Mak T, Shakir A, et al. (2019) Overview of wastewater treatment methods with special focus on biopolymer chitin-chitosan. Int J Biol Macromol 121: 1086-1100.

20. Bernardi F, Zadinelo IV, Alves HJ, Meurer F, dos Santos LD (2018) Chitins and chitosan for the removal of total ammonia of aquaculture effluents. Aquaculture 483: 203-212.

21. Estim A, Saufie S, Mustafa S (2019) Water quality remediation using aquaponics sub-systems as biological and mechanical filters in aquaculture. J Water Process Engineer 30.

22. Ibrahim HM, El-Zairy EMR (2015) Chitosan as biomaterial-structure, properties, and electrospun nanofibers. IntechOpen.

23. Abdel-Latif HMR, Dawood MAO, Menanteau-Ledouble S, ElMatbouli M (2020) The nature and consequences of co-infections in Tilapia: A review. J Fish Dis 43: 651-664.

24. Doan HV, Lumsangkul C, Hoseinifar SH, Hung TQ, Stejskal V, et al. (2020) Administration of watermelon rind powder to Nile tilapia (Oreochromis niloticus) culture under biofloc system: effect on growth performance, innate immune response, and disease resistance. Aquaculture 528.

25. Ahmad AL, Sumathi S, HameedB H (2005) Adsorption of residue oil from palm oil mill effluent using powder and flake chitosan: Equilibrium, and kinetic studies. Water Res 39: 2483-2494.

26. Effendi H, Widyatmoko, Utomo BA, Pratiwi NTM (2020) Ammonia and orthophosphate removal of tilapia cultivation wastewater with Vetiveria zizanioides. J King Saud University Sci 32: 207-212.
27. El-Asely AM, Reda RM, Salah AS, Mahmoud MA, Dawood MAO (2020) Overall performances of Nile tilapia (Oreochromis niloticus) associated with using vegetable oil sources under suboptimal temperature. Aquaculture Nutri 26: 1154-1163.

28. Liu WC, Huang WC (2012) Modelling the transport and distribution of faecal coliform in a tidal estuary. Sci Total Environ 431: 1-8.

29. Bhuyar P, Trejo M, Dussadee N, Unpaprom Y, Ramaraj R, et al. (2021) Microalgae cultivation in wastewater effluent from tilapia culture pond for enhanced bioethanol production. Water Sci Technol.

30. Crab R, Avnimelech Y, Defoirdt T, Bossier P, Verstraete W (2007) Nitrogen removal techniques in aquaculture for a sustainable production. Aquaculture 270: 1-14.

31. Zadinelo IV, Dos Santos LD, Cagol L, de Muniz GIB, de Souza Neves Ellendersen L, et al. (2018) Adsorption of aquaculture pollutants using a sustainable biopolymer. Environ Sci Pollut Res Int 25: 43614370.

32. Fujimoto T, Tsuchiya $\mathrm{Y}$, Terao M, Nakamura K, Yamamoto M (2006) Effects of chitosan solution against Legionella pneumophila, Escherichia coli, and Stapylococcus aureus. Int J Food Microbiol 112 96-101.

33. Jayakumar R, Prabaharan M, Reis RL, Mano JF (2005) Graft copolymerized chitosan-present status and applications. Carbohydrate Polymers 62: 142-158.

34. Nechita P (2017) Application of chitosan in wastewater treatment. In: Shalaby E (eds) Biological Activities and Application of Marine Polysaccharides. IntechOpen.

35. Zheng Y, Wang A (2009) Evaluation of ammonium removal using a chitosan-g-poly (acrylic acid)/rectorite hydrogel composite. J Hazard Mater 171: 671-667.

36. Appunni S, Rajesh MP, Prabakar S (2016) Nitrate decontamination through functionalized chitosan in brackish water. Carbohydr Polym 147: 525-532.

37. Banu HT, Meenakshi S (2017) One pot synthesis of chitosan grafted quarternized resin for the removal of nitrate and phosphate from aqueous solution. Int J Biolog Macromol 104: 1517-1527.

38. Wu FC, Tseng RL, Juang RS (2000) Comparative adsorption of metal and dye on flake- and bead-types of chitosan prepared from fishery wastes. J Hazard Mater 73: 63-75.

39. Crini G, Badot P (2008) Application of chitosan, a natural aminopolysaccharide, for dye removal from aqueous solutions by adsorption processes using batch studies: A review of recent literature. Progress Polym Sci 33: 399-447.

40. Annadurai G (2000) Design of optimum response surface experiments for adsorption of direct dye on chitosan. Bioprocess Engineering 23: 451-455.

41. Nie XD, Fu L (2016) Determination of Trace Impurity Elements in Food Grade Chitosan with Inductively Coupled Plasma Mass Spectrometry. Guang Pu Xue Yu Guang Pu Fen Xi 26: 2621-2624.

42. Deuchi K, Kanauchi O, Shizukuishi M, Kobayashi E (1995) Continuous and massive intake of chitosan affects mineral and fat-soluble vitamin status in rats on a high-fat diet. Biosci Biotechnol Biochem 59: $1211-1216$

43. Coldebella A, Gentelini AL, Piana PA, Coldebella PF, Boscolo WR, et al. (2018) Effluents from fish farming ponds: a view from the perspective of its main components. Sustainability 10: 1-16.

Citation: Saufie S, Estim A, Shaleh SRM, Mustafa S (2021) Evaluation of Nutrient Removal Efficiency with Chitosan: Nutrient Composition and Bacterial Removal in Effluents of Nile Tilapia (Oreochromis niloticus) in the Hatchery. Int J Water Wastewater Treat 
44. DeLong DP, Losordo TM, Rakocy JE (2009) Tank Culture of tilapia. Southern Regional Aquaculture Center, USA.

45. Dullah H, Malek MA, Hanafiah MM (2020) Life cycle assessment of nile tilapia (Oreochromis niloticus) farming in Kenyir Lake, Terengganu. Sustainability 12: 2268.

46. Escudero-Onate C, Martinez-Frances E (2018) A review of chitosanbased materials for the removal of organic pollution from water and bioaugmentation. IntechOpen.

47. FAO (2020) The state of world fisheries and aquaculture 2020 Sustainability in action. Food and Agriculture Organization of the United Nations, Rome, Italy.

48. Giannakas A, Pissanou M (2018) Chitosan/Bentonite Nanocomposites for Wastewater Treatment: A Review. SF J Nanochem Nanotechnol 1: 1010 .

49. Ardila N, Daigle F, Heuzey M, Ajji A (2017) Antibacterial activity of neat chitosan powder and flakes. Molecules 100: 2-19.
50. Chung YC, Chen CY (2008) Antibacterial characteristics and activity of acid-soluble chitosan. Bioresour Technol 99: 2806-2814.

51. Lang Z, Zhou M, Zhang Q, Yin, X, Li Y (2020) Comprehensive treatment of marine aquaculture wastewater by a cost-effective flow-through electro-oxidation process. Sci Total Environ 722: 137812.

52. Shahidi F, Synowiecki J (1991) Isolation and characterization of nutrients and value- added products from snow crab (Chionoecetes opilio) and shrimp (Pandalus Borealis) processing discards. J Agric Food Chem 39: 1527-1532.

53. Vakili $\mathrm{M}$, Rafatullah $\mathrm{M}$, Salamatinia $\mathrm{B}$, Abdullah $\mathrm{AZ}$, Ibrahim $\mathrm{MH}$, et al. (2014) Application of chitosan and its derivatives as adsorbents for dye removal from water and wastewater: A review. Carbohydrate Polymers 113: 115-130.

54. Yen MT, Yang JH, Mau JL (2009) Physicochemical characterization of chitin and chitosan from crab shells. Carbohydrate Polymer 75: 15-21. 